Agro-Science Journal of Tropical Agriculture, Food, Environment and Extension Volume 15 Number 2 May 2016 pp. $23-28$

ISSN 1119-7455

\title{
ANALYSIS OF FACTORS AFFECTING AGRIBUSINESS COOPERATORS' ACCESS TO CREDIT FROM FORMAL SOURCES IN ABIA STATE, NIGERIA
}

\author{
Njoku, Maria-Stella E. \\ Department of Agricultural Economics, Michael Okpara University of Agriculture, \\ Umudike, Abia State, Nigeria \\ Correspondence: mariastellanjoku@yahoo.co.uk
}

\begin{abstract}
The study focused on determinants of Agribusiness Cooperators' access to credit in from formal sources in Abia State, Nigeria. Specifically, the study examined the socioeconomic characteristics of respondents; estimated the determinants of access to credit and ascertained the challenges associated with Agribusiness Cooperators' borrowing from formal sources. Multistage sampling technique was adopted in sampling for location and respondents. A total of 150 respondents were sampled from list of Agribusiness Cooperators in the various communities. Data were collected using questionnaire administered on respondents using interview schedules and observation. Data were analysed using descriptive and inferential statistics such as percentages, means and the Ordinary Least Squares multiple regression model. Results indicate that Agribusiness Cooperators in the study area are predominantly young, productive and literate with average farming experience of 7 years. Findings further showed that the cooperators are predominantly males, smallholders with mean household size of 6 persons and mean income of N45,878.00 per farming season. Results of the regression model indicated that farm size, education and loan period showed expected positive signs a priori and were significant at various probability levels. Contrary to a priori expectation, experience showed a negative sign and was significant at 10\% level. High interest rate, delay in loan disbursement and reluctance in repaying loans were rated the most dominant challenges to borrowing from formal sources. Based on the findings, it was recommended that cooperatives should be encouraged to organize periodic capacity building exercises for members to keep them abreast of developments vis-à-vis agribusiness investment and credit access.
\end{abstract}

Key words: loan, interest rate, loan disbursement and cooperatives

\section{INTRODUCTION}

Credit is considered as a catalyst that activates other factors of production and makes under-used capacities functional for increased production (Ijere, 1998). Thus farm credit plays a crucial role in agricultural and rural development as it enables farmers reap economies of scale, venture into new fields of production, employ new technologies and empower them to provide utilities for a widening markets. Farm credit plays this role because it bridges the capital gap that exists in agricultural production.

One of the reasons for the decline in the contribution of agriculture to the economy of Nigeria is the lack of a stable national credit policy and paucity of credit institutions which can assist farmers (Afolabi, 2008). Credit is an important instrument for improving the welfare of the poor directly through consumption smoothening that reduces their vulnerability to short term income. It also enhances the production capacity of the poor resource farmers through financing investment in their human and physical capital. There is no doubt that in recent times, considerable interest has been shown by agricultural economists, planners, policy makers, agribusiness managers, agriculturists, and financial institutions on the need to pay more attention to farmers in Nigeria. This deserved attention is a call from the conviction that in the short-run, Nigeria can rely on farmers to supply the bulk of the food and raw materials for our industries to feed the rapid growing population in Nigeria (Ezeh, 2003).

Farm credit could be obtained from either the formal sources which are the Money Deposit Banks and government owned institutions, or the informal sources which are the self-help-group, money lenders, cooperatives and non-governmental organizations (NGOs). However, Aryeetey (1997) stated that the informal rural financial sources in Africa perform better than the formal sources because they have adapted to the high-risk environment. He further advised that the formal sector should learn from the informal institutions. Subsequently, the cooperatives 
and NGOs which are formalized informal sources of credit in both rural and urban sectors are being considered as more credible sources to both farmers and small scale enterprises. Nevertheless, these informal institutions do not seem to be fulfilling this obligation as evidence still abounds that farmers are still in dire need of adequate capital (Oni, 1999).

Credit provision is one of the principal components of rural development, which helps to attain rapid and sustainable growth of agriculture. Rural credit is a temporary substitute for personal savings, which catalyses the process of agricultural production and productivity. To boost agricultural production and productivity, farmers have to use improved agricultural technologies. However, the adoption of modern technologies is relatively expensive and small farmers cannot afford to self finance their ventures. As a result, the utilization of agricultural technologies is very low.

Against this backdrop, the study therefore analyzed the factors affecting agribusiness cooperators access to formal credit in Abia State, Nigeria. Specifically, the study examined the socioeconomic characteristics of the respondents; determined the factors influencing access to formal credit and ascertained the problems associated with borrowing by the cooperators.

\section{MATERIALS AND METHODS}

The study was conducted in Abia State. The state is located within Southeastern Nigeria and lies between longitudes $04^{\circ} 45^{\prime}$ and $06^{\circ} 07^{\prime}$ East and Latitudes $07^{\circ} 00^{\prime}$ and $08^{\circ} 10^{\prime}$ North. Abia State is bounded by Imo state at the western border; Ebonyi and Enugu States at the North; Cross River and Akwa-Ibom States at the East and Rivers state at the south. The Southern part of the state lies within the riverine part of Nigeria. It is lowlying with a heavy rainfall of about $2400 \mathrm{~mm} /$ year especially intense between the months of April through October. Its population stood at about $2,883,999$ persons with a relatively high density at 580 persons per square kilometer (NPC, 2007).

Table 1: Distribution of cooperators by age

\begin{tabular}{lcc}
\hline Age (in years) & Frequency & Percentage $(\%)$ \\
\hline $20-29$ & 54 & 36.00 \\
$30-39$ & 50 & 33.33 \\
$40-49$ & 37 & 24.6 \\
$50-59$ & 9 & 6.00 \\
Total & 150 & 100.00 \\
Mean & 34.86 & \\
\hline Source: Field Survey, 2015 & &
\end{tabular}

For data collection, the study adopted a multistage sampling technique. In the first stage, three Local Government Areas (LGAs) namely Umuahia North, Isiukwuato and Isiala Ngwa North were selected purposively from each of the three agricultural zones of the state based on the prevalence of cooperative societies in these LGAs. The second stage involved random selection of five communities across the three LGAs chosen, making a total of 15 communities. The final stage involved the random sampling of ten cooperators from lists of cooperators Beneficiaries of credit facilities from formal sources, from each of the selected communities in each of the LGAs. This gave an aggregate of one hundred and fifty cooperators which is the sample size for the study.

The study employed primary data for its analysis. The primary data were elicited from pretested and structured questionnaire which were administered on the cooperators in the study area using interview schedules and observation method.

Statistical and econometric tools were employed in analyzing data obtained for the study. These included the use of descriptive statistics to examine the socioeconomic characteristics and the problems of the cooperators associated with borrowing and the application of multiple regressions model to analyze factors influencing access to formal credit.

The multiple regression model was explicitly specified thus:

$$
Y_{i}=b_{0}+b_{1} X_{1}+b_{2} X_{2}+b_{3} X_{3}+b_{4} X_{4}+b_{5} X_{5}+
$$
$b_{6} X_{6}+b_{7} X_{7}+b_{8} X_{8}+b_{9} X_{9}+b_{10} X_{10+} e_{i} \ldots$ (i); where $\mathrm{Y}_{\mathrm{i}}$ is rate of accessibility to credit (\%), defined as the percentage ratio of the amount of credit applied to the amount obtained, $\mathrm{X}_{1}$ is sex $($ male $=1$; female $=$ 0 ), $X_{2}$ is age (years), $X_{3}$ is marital status (married $=1$; otherwise $=0), X_{4}$ is household size (number of persons), $X_{5}$ is income (Naira), $X_{6}$ is farm size (ha), $\mathrm{X}_{7}$ is education (years), $\mathrm{X}_{8}$ is experience (years), $\mathrm{X}_{9}$ is distance between homestead and loan source $(\mathrm{km})$, $\mathrm{X}_{10}$ is loan period (months), and $\mathrm{e}_{\mathrm{i}}$ is error term.

\section{RESULTS AND DISCUSSION}

\section{Age of Cooperators}

As shown in Table 1, about $69 \%$ of the farmers fell within the age bracket of 20 and 39 years, which implies that most of them are still active and fall within the age bracket of young people while only $30.67 \%$ of the cooperators fit into age category of 40 years and above. The implication is that the agribusiness cooperatives in the study area are predominantly populated by young and active individuals. This result is in agreement with Idoge (2013), who found that majority of cooperative members cluster within 31-50 years age bracket in a related study in the Niger-Delta of Nigeria. 


\section{Educational level of respondents}

Data on educational level in Table 2 shows that $10 \%$ of the cooperators had no formal education. Those who had primary education represented $16 \%$ while $42 \%$ received secondary education. Out of $90 \%$ who had one formal education or the other, $32 \%$ had tertiary education. By implication, the study area is grossly dominated by literate cooperators, as the mean level of education (11.12 years) falls within the range of secondary education According to Etonihu et al. (2013), educated farmers are likely to understand the benefits of credit in modern production and comprehend extension information on sources and utilization of credit.

\section{Experience}

The data on farming experience as shown in Table 3 shows that about $48 \%$ of the cooperators have farming experience ranging from 1 to 5 years while only $2.67 \%$ have been in the production business for above 16 years. It further showed that about $50 \%$ of the respondents had farming experience of 6-15 years. With average farming experience of about 7 years, the cooperators in Abia State have reasonable wealth of farming experience and so, have the capacity of maximizing their output and profit at minimum cost. It thus supports the findings of Njoku and Odii (1991) that farming experience enhances efficient use of scarce resources by farmers in Nigeria.

\section{Farm Size}

As shown in Table 4, about $52 \%$ of the agribusiness cooperators have farms that are less than 5 ha in size. About 23\% own farms between 5 and 8.99 ha while about $25 \%$ possess farms of size 9 ha and above with a mean size of 5.64 ha in Abia State. The implication of the results is that the farmer cooperators are predominantly smallholders probably because of the limited availability of farmland and constraints imposed by land fragmentation. According to CTA (2000), a characteristic feature of the agricultural production system in developing countries is that a disproportionately large fraction of the agricultural output is in the hands of these smallholder farmers whose average holding is about 1-3 ha.

\section{Household Size}

Data on household size in Table 5 showed that majority of the cooperators, about $53 \%$ have household size of between 6 and 10 persons. About $42 \%$ maintained household size of $1-5$ persons. With an average size of 6 persons per household, it means that the cooperators have bloated household sizes which have a major implication for provision of farm labour as observed by Ezeh and Nwachukwu (2010).
Table 2: Distribution of cooperators by education

\begin{tabular}{lcc}
\hline Level of Education in years & Frequency & Percentage (\%) \\
\hline 0 (No formal education) & 15 & 10 \\
$1-6$ (Primary education) & 24 & 16 \\
$7-12$ (Secondary education) & 63 & 42 \\
13-18 (Tertiary) & 48 & 32 \\
Total & 150 & 100 \\
Mean & 11.12 & \\
\hline
\end{tabular}

Source: Field Survey, 2015

Table 3: Distribution of cooperators by experience

\begin{tabular}{lcc}
\hline Experience (in years) & Frequency & Percentage (\%) \\
\hline $1-5$ & 71 & 47.33 \\
$6-10$ & 59 & 39.33 \\
$11-15$ & 16 & 10.67 \\
16 and above & 4 & 2.67 \\
Total & 150 & 100.00 \\
Mean & 7.15 & \\
\hline Source: Field Survey, 2015 & &
\end{tabular}

Table 4: Distribution of cooperators by farm size

\begin{tabular}{lcc}
\hline Farm size (in ha) & Frequency & Percentage (\%) \\
\hline $0.10-4.99$ & 78 & 52.00 \\
$5.0-8.99$ & 50 & 23.33 \\
9.0 and above & 35 & 24.6 \\
$5.0-8.99$ & 37 & 24.67 \\
Total & 150 & 100.00 \\
Mean & 5.64 & \\
\hline
\end{tabular}

Source: Field Survey, 2015

Table 5: Distribution of cooperators by household size

\begin{tabular}{lcc}
\hline Household size (No. of persons) & Frequency & Percentage $(\%)$ \\
\hline $1-5$ & 63 & 42.00 \\
$6-10$ & 80 & 53.33 \\
$11-15$ & 7 & 4.67 \\
Total & 150 & 100.00 \\
Mean & 6.26 & \\
\hline
\end{tabular}

Source: Field Survey, 2015

Table 6: Distribution of cooperators by sex

\begin{tabular}{lcc}
\hline Sex & Frequency & Percentage (\%) \\
\hline Male & 78 & 52.00 \\
Female & 72 & 48.00 \\
Total & 150 & 100.00 \\
\hline
\end{tabular}

Source: Field Survey, 2015

Table 7: Distribution of cooperators by marital status

\begin{tabular}{lcc}
\hline Marital Status & Frequency & Percentage $(\%)$ \\
\hline Married & 111 & 74.00 \\
Single & 39 & 26.00 \\
Total & 150 & 100.00 \\
\hline Source & &
\end{tabular}

Source: Field Survey, 2015

Table 8: Distribution of cooperators by distance to source of loan

\begin{tabular}{lcc}
\hline Distance (in kilometers) & Frequency & Percentage $(\%)$ \\
\hline $1-5$ & 12 & 8.00 \\
$6-10$ & 94 & 62.67 \\
$11-15$ & 36 & 24.00 \\
$16-20$ & 4 & 5.33 \\
Total & 150 & 100.00 \\
Mean & 10.47 & \\
\hline Source: Field Survey, 2015 & &
\end{tabular}


Table 9: Distribution of cooperators by amount borrowed

\begin{tabular}{lcc}
\hline Amount (in Naira) & Frequency & Percentage $(\%)$ \\
\hline $1-250,999$ & 132 & 88.00 \\
$251,000-500,999$ & 16 & 10.00 \\
$501,000-750,999$ & 1 & 0.67 \\
$751,000-1,000.999$ & 1 & 0.67 \\
Total & 150 & 100.00 \\
Mean & 102,999 & \\
\hline
\end{tabular}

Source: Field Survey, 2015

Table 10: Distribution of cooperators by income

\begin{tabular}{lll}
\hline Amount (in Naira) & Frequency & Percentage $(\%)$ \\
\hline $1,000-30,999$ & 17 & 11.33 \\
$31,000-60,999$ & 81 & 54.00 \\
$61,000-90,999$ & 8 & 5.33 \\
$91,000-120,999$ & 1 & 0.67 \\
Total & 150 & 100.00 \\
Mean & 45,878 & \\
Minimum & 3000 & \\
Maximum & 95,000 & \\
\hline Source: Field Survey, 2015 &
\end{tabular}

Table 11: Factors affecting access to formal credit by agribusiness cooperators

\begin{tabular}{|c|c|c|c|c|}
\hline Variables & Linear & Double log & Semi log & Exponential \\
\hline \multirow{2}{*}{ Constant } & $95.250 *$ & $5.195 * * *$ & 194.444 & $4.565 * * *$ \\
\hline & (2.596) & $(3.697)$ & (0.759) & (19.165) \\
\hline \multirow{2}{*}{$\operatorname{Sex}\left(X_{1}\right)$} & -11.737 & -0.055 & -16.270 & 0.068 \\
\hline & $(-0.769)$ & $(-0.531)$ & $(-2.694)$ & (1.942) \\
\hline \multirow{2}{*}{ Age $\left(\mathrm{X}_{2}\right)$} & 0.181 & 0.109 & 3.172 & 0.004 \\
\hline & $(0.200)$ & $(0.506)$ & $(0.081)$ & (0.776) \\
\hline Marital & -0.318 & -0.074 & -0.165 & -0.041 \\
\hline Status $\left(\mathrm{X}_{3}\right)$ & $(-0.054)$ & $(-2.962)$ & $(-0.009)$ & (1.116) \\
\hline Household & -1.769 & -0.061 & -4.387 & -0.011 \\
\hline size $\left(\mathrm{X}_{4}\right)$ & $(-2.391)$ & $(-0.549)$ & $(-0.217)$ & $(-0.657)$ \\
\hline Income & 9.887 & $0.111 *$ & $17.067 *$ & 0.076 \\
\hline$\left(\mathrm{X}_{5}\right)$ & (0.699) & (2.223) & (2.085) & $(0.865)$ \\
\hline Farm Size & 0.591 & -0.032 & -2.383 & $0.038 * * *$ \\
\hline$\left(\mathrm{X}_{6}\right)$ & (3.111) & $(-0.378)$ & $(-2.380)$ & $(2.923)$ \\
\hline Education & -5238 & -0.082 & -10.674 & $0.818^{* * * *}$ \\
\hline$\left(\mathrm{X}_{7}\right)$ & $(-1.282)$ & $(-0.754)$ & $(0.539)$ & $(3.326)$ \\
\hline Experience & -1.903 & -0.111 & -13.830 & $-0.015^{*}$ \\
\hline$\left(\mathrm{X}_{8}\right)$ & $(-1.520)$ & $(-1.545)$ & (1.053) & $(-1.888)$ \\
\hline Distance & -2.514 & $0.520 * * *$ & -2.368 & $-0.045 * * *$ \\
\hline$\left(\mathrm{X}_{9}\right)$ & $(-2.175)$ & $(4.444)$ & $(-0.111)$ & $(-6.429)$ \\
\hline Loan Period & $9.663^{* * *}$ & 0.022 & $24.297 *$ & $0.024 * *$ \\
\hline$\left(\mathrm{X}_{10}\right)$ & $(7.441)$ & $(0.360)$ & (2.188) & (3.011) \\
\hline $\mathrm{R}^{2}$ & 0.511 & 0.449 & 0.507 & 0.614 \\
\hline F-ratio & $6.270 * * *$ & $5.185^{* * * *}$ & $1.510^{*}$ & $7.673 * * *$ \\
\hline
\end{tabular}

Table 12: Problems of cooperators regarding borrowing

\begin{tabular}{lccc}
\hline Problems & Frequency & Percentage & Rank \\
\hline High interest rate & 55 & 36.67 & $1^{\text {st }}$ \\
Delay in loan disbursement & 36 & 24.00 & $2^{\text {nd }}$ \\
Credit Rationing & 24 & 16.00 & $4^{\text {th }}$ \\
Reluctance in repaying & 30 & 20.00 & $3^{\text {rd }}$ \\
Transaction costs & 5 & 3.33 & $5^{\text {th }}$ \\
\hline
\end{tabular}

Source: Derived from Field Survey, 2015

\section{Sex of Respondents}

The distribution of the agribusiness cooperators by sex shown in Table 6 indicates that the population of men $(52 \%)$ is dominant in the cooperatives. According to Woldu et al. (2013), women's participation in agribusiness cooperatives is generally low especially in the developing countries. Those women who are members face problems and constraints that adversely affect the benefits that their membership in such groups should bring. The results also indicate that one of the main reasons for women's lower participation in agricultural cooperatives compared to men is related to their limited decision-making power in the household.

\section{Marital Status}

The distribution of the cooperators by marital status as depicted by Table 7 showed that $74.00 \%$ were married while $26.00 \%$ disaggregated into different single categories such as single, divorced, separated etc. The result shares similar outcomes with Toluwase and Apata (2013) who found that $65.8 \%$ of the cooperators are married while Ofuoku and Urang (2009) recorded $73.6 \%$ among married cooperators. They also observed that married people have much more responsibilities to bear than their single counterparts and as such, employ the instrumentality of cooperatives as a way of cushioning the effect.

\section{Distribution of the Cooperators by Distance}

The distribution of the cooperators by distance between their source of loan and homestead is presented in Table 8 . From the result, about $63 \%$ of the cooperators cover between 6 and $10 \mathrm{~km}$ before reaching their loan source while $8 \%$ cover between 1 and $5 \mathrm{~km}$. This implies that the longer the distance, the less the propensity to borrow. This is because increased distance commands more expenses on transportation and thus, increases the overhead and consequent cost of loan procurement. This result is in line with a priori expectation.

\section{Amount borrowed}

The distribution of the cooperators by the amount received is shown in Table 9. About $88 \%$ of them received between $\mathrm{N} 1,000$ and $\mathrm{N} 250,999$ and this represents the majority. Due to paucity of the amount received as loan, one can deduce that the cooperators seem not to be making efforts to commercialize and enlarge their scale of operation.

\section{Income}

Income distribution among the respondents in the study area as shown in Table 10 ranged from N3,000 to N120,999 with the vast majority earning between $\mathrm{N} 31,000$ and N60,999 per farming season. With a 
mean of $\mathrm{N} 45,878$, it could be inferred that the agribusiness cooperators in the area are generally low income earners. This is because their mean income on per month basis is even less than the approved national minimum wage of N18,000.

\section{Analysis of Factors Affecting Agribusiness Cooperators' Access to Formal Credit}

The analysis of factors affecting access to formal credit by agribusiness cooperators was realized by a multiple regression model. Four functional forms were tried namely linear, double log, semi-log and exponential; with the exponential function emerging as the lead equation based on its fulfillment of certain statistical and econometric criteria such as number and sign identities of the significant variables, magnitude of $\mathrm{R}^{2}$ and significant F-Ratio, etc.

The results of the analysis are presented in Table 11. The coefficients of farm size, education and loan period possessed expected positive signs and were significant at various probability levels. This implies that the cooperators loan accessibility rate is enhanced by increasing farm size, education and loan period. Thus, any $1 \%$ increase in accessibility rate is triggered by $0.038,0.818$ and $0.024 \%$ increase in farm size, education and loan period, respectively. These results agree with those of Kohansal et al. (2008) who reported a positive relationship between farm size and credit accessibility, on one hand and those of Oke et al. (2007) who reported a positive coefficient for education in a similar study in southeastern Nigeria, on the other.

Contrary to a priori expectation, experience showed a negative coefficient at $10 \%$ probability level, implying that experienced cooperators are averse to loan access. This is plausible when people allow their ugly experience in the past with respect to loan procurement to haunt them and as such exert negative influence on efforts towards accessing loans. Distance posted the anticipated negative coefficient, implying that the longer the distance between the cooperators' homestead and source of loan, the less likely to access credit. Similarly, Fakayode and Rahji (2009), Ayamga et al. (2006) and Akudugu (2012) averred that the closer to the source, the higher the probability of the decision to demand credit.

In terms of diagnostic tests, the coefficient of determination $\left(\mathrm{R}^{2}\right)$ was 0.614 indicating that about $61 \%$ of the variations in the rate of access to credit was explained by changes in the explanatory variables. The F-ratio of 7.673 was significant at $1 \%$ level of probability level, implying goodness of fit that the variables included in the model are correct and confirms the explanatory power of the model.
Cooperators' Problems associated with Borrowing To assess the problems experienced by the cooperators in relation to borrowing, descriptive statistics were employed and the result presented in Table 12. From Table 12, it could be observed that among the problems of the cooperators associated with borrowing, $24.00 \%$ claimed that delay in loan disbursement was a major problem associated with borrowing while $16.00 \%$ averred that credit rationing was the issue on the part of the credit agency. However, high interest rate and reluctance in repaying loans were rated the most dominant and second most dominant problems by $36.67 \%$ and $20.00 \%$ of the respondents respectively. In line with a priori expectation and in conjunction with the findings of Kohansal and Mansoori (2009), interest rate has an inverse relationship with borrowing.

\section{CONCLUSION}

Having assessed the factors affecting access to formal credit among farmer cooperators in Abia State, the emerging realities are revealing and worrisome. Findings of the study showed that the agribusiness cooperators are predominantly young which means that they are within active labour force and should be productive. They have average farming experience of seven years. Results further showed that the cooperators are predominantly male, smallholders with mean household size of six persons and mean income of N45,878.00 per farming season. They are also literate which implies that they are capable of understanding the benefits of credit in modern production and comprehend extension information on sources and utilization of credit. Result of the regression model indicated that the coefficients of farm size, education and loan period showed expected positive signs a priori and were significant at various probability levels. Contrary to $a$ priori expectation, experience showed a negative sign and was somewhat significant. High interest rate, delay in loan disbursement and reluctance in repaying loans were rated the most dominant challenges to borrowing from formal sources. The need to address fundamental issues such as negative impact of experience on loan accessibility as shown by the study becomes very imperative. The study concludes that confrontation of these fundamental issues through value re-orientation and deliberate policy options by the relevant arms of government is a sure way of enhancing accessibility while making spirited efforts to attain food security in Nigeria. Based on the findings, the study recommends that given that education posted a positive coefficient, it is important that extension education be intensified to raise the consciousness and knowledge base of the cooperators. 
Moreover, the cooperatives should be encouraged to organize periodic capacity building exercises such as seminars for members to keep them abreast of developments vis-à-vis agribusiness investment opportunities and credit access. The cooperators should be given more access and higher amount of credit to enable them increase their increase their scale of operation and farm size.

\section{REFERENCES}

Afolabi, C.J. (2008). Loan repayment and technical assistance among smallholder maize farmers in Nigeria. African Review of Money \& Banking, A Supplement of Savings \& Development Journal, 1, 64-72

Aryeetery, L. (2006). Assessing factors affecting the repayment rate of microfinance institutions: a case study of village credit institutions of Gianyar, Bali. Gadjah Mada Int. Journal of Business, 8(2), 247-273

Ayanga, M.U. Leaman, S.H., Cook, T.J., and Stewart, L.S. (2006), Factors affecting loan acquisitioned repayment patterns of smallholder farmers in Inlka North-East of Delta State Nigeria. Journal of Sustainable Tropical Agricultural Research, 9, 61-64

Akudugu, C.J. (2012). Loan repayment and technical assistance among smallholder maize farmers in Nigeria.African Review of Money and Banking. A Supplement of Savings and Dev. Journal, 1, 64-72

CTA (2000). Framework for Credit Risk Management. CTA Publishing, UK

Derban, W.K., Binner, J.M., and Mullineux, A. (2005). Loan repayment performance in community development finance institutions in the UK. Small Business Economics, 25, 319-332

Ezeh, C.C. (2003). The role of informal finance in rural areas of Nigeria. In: Rural Development in Nigeria: Concepts, Processes and Prospects. (eds). Eboh, E.C; Okoye, C.U; and D. Ayichi.Enugu Auto-Century Publishing Coy. LTD

Etonihu, S., Mejeha R.O., Obunadike A. (2013). Access to Bank Credit in sub-Saharan Africa: Key Issues and Reform Strategies. IMF Working Paper WP/05/166 IMF Washington
Ezeh, C.C., and Nwachukwu, I.N. (2010). Determinants of loan repayment under the indigenous financial system in Southeast, Nigeria. The Social Sciences, 2(2), 116120

Fakayode, M. and Rahji U.K (2009). Microfinance repayment performance in bangladesh: how to improve the allocation of loans by MFIs. World Development, 32(11), 1909-1926

Ijere, M.O. (1998). Agricultural credit and economic development. In: Ijere M.O., Okorie A. (eds.) Readings in Agricultural Finance. Longman Lagos, pp. 4-9

Idoge, P.C. (2013) Loan Repayment and its Determinants under the Agricultural Credit Guarantee Scheme in Imo State, Nigeria. Afr. Rev. Money Fin. Bank., 3(2), $45-47$

Kohansal, S. and Mansoori C.B. (2009) Niche Lending in Agriculture. J. Agric. Lending. American Bankers Association 2(4), Lagos, Nigeria

Njoku, J.E. and Odii, M.A.C.A. (1991). Determinants of Loan Repayment under the special Emergency Loan Scheme (SEALS) in Nigeria: A Case Study of Imo State. Afr. Rev. Money Fin. Bank., 3(1), 165-169

Njoku, J.E. (1997). Determinants of loan repayment under the special emergency loan scheme (SEALS) in Niger: A case study in Imo state. African Review of Money Finance and Banking, 1, 39-51

Ofuoku, J.O., and Urang, O.E. (2009).Determinant of loan repayment among smallholder farmers inOgbomoso Agricultural Zone of Oyo State, Nigeria. Journal of Social Science, 17(1), 59-62

Oni, A.S. (1999). Determinants of smallholder loan repayment performance: evidence from the Nigeria micro-finance system. Retrieved May 9, 2010 from Olomola.pdf

Toluwase, G. A. and Apata, G.A (2013).Overcoming selection bias in microcredit impact assessments: a case study in Peru. Journal of Development Studies, 44(4), 504-518

Woldu, L., and Fidler, P. Rambabu, P.D., and Eswaran, Y.P. (2013). The Informal Sector and Microfinance Institutions in West Africa. World Bank. Washington, $21-42$ 